\title{
Lessons for a viable water recycling industry
}

Amit Prempal Chanan MEng, MEM, MSC General Manager Strategic Assets, State Water Corporation, Sydney, Australia

Saravanamuth Vigneswaran PhD

Professor, School of Civil and Environmental Engineering, University of Technology Sydney, Sydney, Australia
Jaya Kandasamy PhD

Associate Professor, School of Civil and Environmental Engineering, University of Technology Sydney, Sydney, Australia

Bruce Simmons PhD

Adjunct Associate Professor, School of Natural Sciences, University of Western Sydney, Richmond, Australia

The platform on which the Labour government came to power in Australia in November 2007 included a policy of setting a national wastewater recycling target of $30 \%$ by the year 2015 . A similar target-based approach was followed by the solid waste recycling industry in Australia the policy of which focused on supply and did not adequately acknowledge the price competitiveness of the product and its demand. This paper highlights the lessons from the solid waste recycling industry and applies them to the water recycling sector. A sound water pricing regime that reflects the true costs of water and a competitive water industry is offered as a better policy alternative to setting recycling targets.

\section{Introduction}

Water recycling is defined as the effective use of water that has been treated as an effluent from another use (Oron, 2003). Given the technological advancements that now allow effluent treatment to high levels, wastewater is now widely regarded as a water resource and not as a waste. Over the last couple of decades a number of guidelines and criteria for water recycling have been developed across the world. Some notable ones include (Tsagarakis, 2005):

(a) the World Health Organisation 1989 guidelines for the use of wastewater in agriculture and aquaculture

(b) the Food and Agricultural Organisation 1992 guidelines on wastewater treatment and its use in agriculture

(c) the United States Environmental Protection Agency's 1992 guidelines for water reuse

(d) the 1991 European wastewater directive, which called for 'treated wastewater to be reused whenever appropriate'.

In Australia, the 2004 national water initiative led to progressive urban water reforms throughout the country. One of the key objectives under this urban water reform programme is 'to encourage recycling of wastewater where cost effective' (Radcliffe, 2008).

The Environment Protection and Heritage Council of Australia and New Zealand (EPHC), the Natural Resource Management Ministerial Council and the National Health and Medical Research Council of Australia have developed a suite of guidelines for the safe use of recycled water. The first of the Australian guidelines for water recycling, managing health and environmental risks, was released in 2006 and, since then, complementary phase 2 guidelines concerning (EPHC, 2008):

(a) augmentation of drinking water supplies (b) stormwater harvesting and reuse

(c) managed aquifer recharge.

have been added to the suite.

Water recycling is now well recognised as a practical option for urban water supply management in Australia. In 2007, a Labour government was elected to office with a policy platform that included setting a national wastewater recycling target of $30 \%$ by the year 2015 (Albanese, 2006). The Australian Greens (TAG), who currently hold the balance of power in the Australian federal parliament also believe in the principle of setting per capita targets for water recycling (TAG, 2009).

\section{Water recycling in Australia}

According to Marsden Jacob Associates (MJA, 2008), over the past few years there has been a noticeable general increase in implementing water recycling initiatives across Australia. This increase is driven primarily by the current severe drought across the continent and is assisted by available federal funding for implementing water security initiatives.

Figure 1 shows the extent of water recycling as a percentage of treated water. In six out of eight Australian states and territories (Victoria (VIC), Queensland (QLD), South Australia (SA), Western Australia (WA), Australian Capital Territory (ACT) and Northern Territory (NT)), a significant increase in water recycling was achieved over the 10-year period from 1996 to 2006. In New South Wales (NSW), there was an initial increase in water recycling between 1996 and 2001, but levels have since dropped. Similarly in Tasmania (TAS), after an initial increase over the first 5 years from 1996, water recycling levels have slightly reduced. Most Australian states and territories, however, have progressively increased their water recycling percentage since 1996/97. 


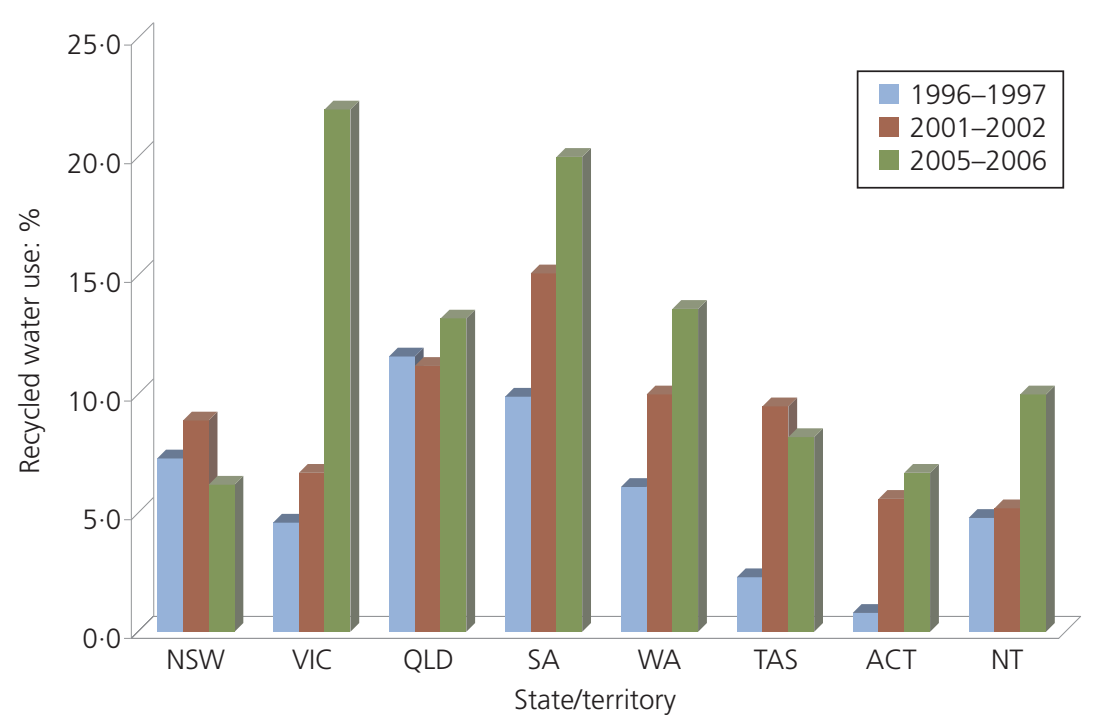

Figure 1. Recycled water use in Australian states and territories as a proportion of total treated water (MJA, 2008)

According to the Water Services Association of Australia (WSAA), on average, Australian cities recycle around $9 \%$ of wastewater (MJA, 2008). When compared with capital cities, it would appear that regional urban centres in Australia recycle a much higher proportion of their wastewater (Figure 2).

All of the major capital cities shown in Figure 2 are serviced by large water utilities that have developed water supply security strategies for the future. Indeed, Perth, Adelaide, Melbourne, Sydney and Brisbane all apply selected desalination as a preferred way to augment and manage future water supplies. According to MJA (2008), given the extensive planning and implementation of desalination projects, the most efficient water supply augmentation projects to cater for future demand have already been implemented in these cities. Significant investment in water recycling projects by water utilities servicing major capital cities is required if the national water recycling target of $30 \%$ by 2015 is to be met.

\section{Lessons from the waste recycling industry}

Recycling solid waste, in particular newspaper waste, is like second nature to most Australians. Newspaper recycling levels increased from 53\% in 1995 to well over $75 \%$ in 2006, making

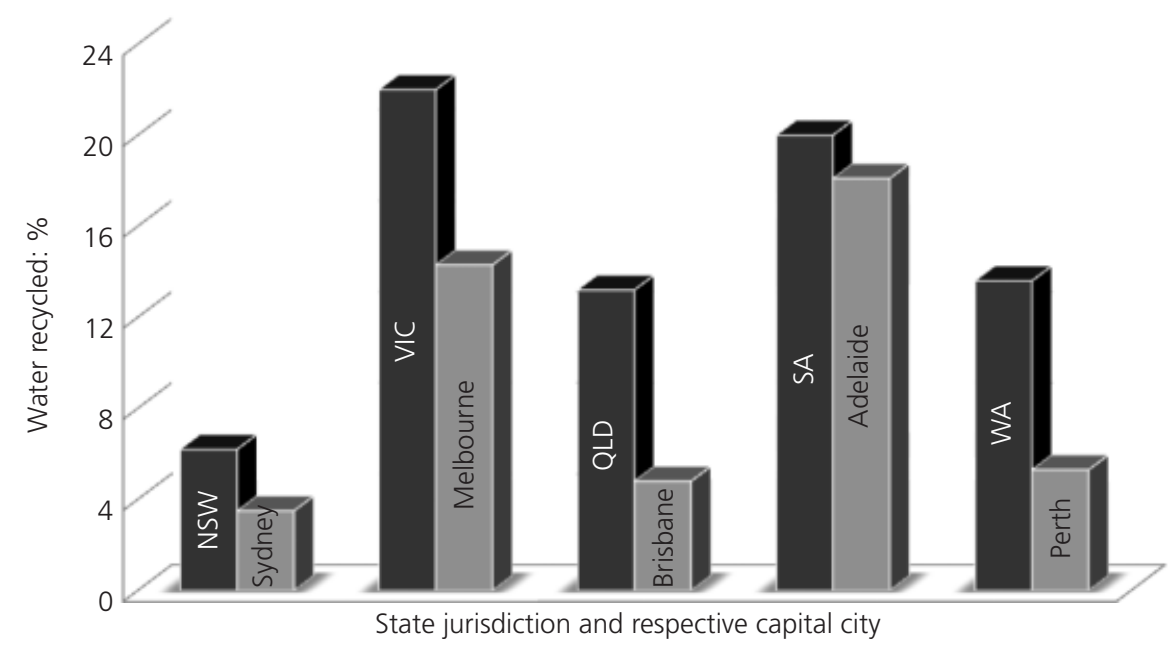

Figure 2. Comparison of state-wide water recycling and recycling in the respective capital cities in 2005/06 (MJA, 2008; Radcliffe, 
Australia one of the leading newspaper recycling nations in the world (Graham, 2006).

The Packaging Council of Australia (PCA, 2010) suggests that 'recycling has acquired something approaching motherhood status in Australia'. However, vast community support for recycling alone does not guarantee the long-term viability of recycling. According to the PCA (2010), the key to effective long-term recycling is the availability and development of viable markets, which can only occur if the materials being recycled become tradable commodities at market prices. The PCA (2010) cautions against policy directives that concentrate on setting artificial targets and suggests that the focus should instead be on getting the economics of recycling right.

There are indeed some noteworthy parallels between target-based policy initiatives for waste recycling in the last century and current water recycling targets. Similarly to the current water recycling target, waste recycling targets were developed with focus on supply alone. The primary purpose behind these targets was to reduce the amount of waste going to landfill. As outlined in Figure 3, an increase in supply of recycled material $\left(\Delta Q_{\mathrm{s}}\right)$ to meet the target results in shifting the supply curve upwards so that additional supply could be provided regardless of the market price. In a competitive market this results in suppliers lowering prices in order to increase the demand for recycled materials.

According to Planet Ark (PA, 2005), these targets resulted in an oversupply of recycled materials in an economy that is supplied with affordable virgin raw materials. Recycling companies and local councils consequently struggled financially to recoup recycling costs from the sale of recovered/recycled materials. By recycling their waste, local councils in Sydney saved A $\$ 0.5$ million (Australian dollars) on waste disposal costs in 1989, but made a loss of A $\$ 0.4$ million. Similarly, according to the Industry Commission (IC, 1990), council recycling schemes in Melbourne in 1989 operated at an overall financial loss of A $\$ 0 \cdot 7$ million. The IC review (IC, 1990) concluded that many councils in Australia spent

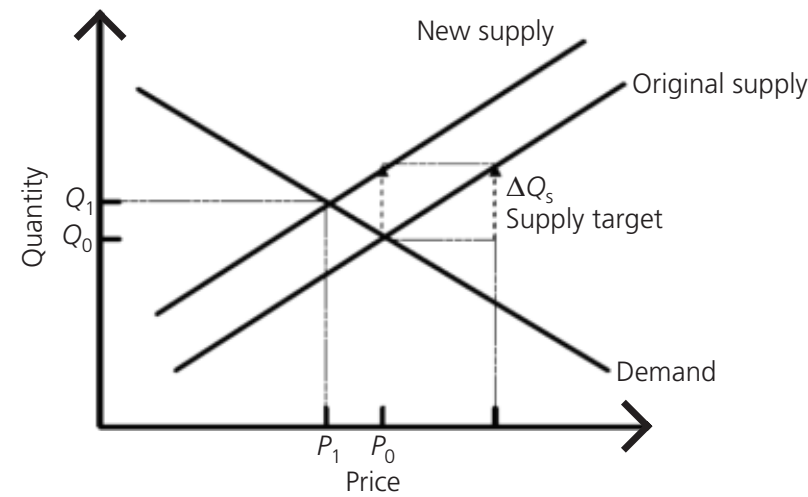

Figure 3. Supply target based policy impacts on equilibrium pricing more on developing and running recycling schemes than they earned through avoided waste disposal costs and the sale of recycled materials. To sustain waste recycling and supply, demand for recycled products had to be created. Initially, consumers took up the cause and recycled products were 'in vogue' in the late 1980s and early 1990s (PA, 2005). However, due to their often higher price many people shifted back to cheaper virgin products.

The price users are willing to pay for recycled products reflects the qualities of those products relative to products made from virgin materials (IC, 1991). Where the recycled product is very different from the original, and is not considered substitutable for the virgin product, much lower prices apply. Given the community's reluctance to accept potable water reuse (Dolnicar and Schafer, 2009), it would be reasonable to conclude that recycled water is not yet considered a direct substitute for virgin water and therefore users will be reluctant to pay the same price for recycled water as they do for potable water. The only exception to this may apply in the case of industrial reuse, where the quality of recycled water might be preferred over virgin water in some industrial processes.

Current demand-side strategies such as green purchasing policies that allow additional budgets for purchasing recycled products given their greater purchase price have been critical in keeping the waste recycling industry viable (PA, 2005). The solid waste recycling experience in Australia has made it abundantly clear that the economics of recycled products defines the long-term success or failure of policy directives. A waste recycling policy that focused on supply and did not adequately acknowledge the price competitiveness of the product and its demand has revealed some useful lessons. It is only prudent for the water recycling sector to learn from these and develop a more informed policy platform for the future.

\section{Water pricing in Australia}

Current water pricing arrangements in Australia are characterised by periodic price reviews ( $3-5$ yearly) by pricing regulators using the building blocks methodology. Under this methodology, an annual revenue requirement of the utility is calculated based on the estimated funds it requires to efficiently deliver its required services and meet its regulatory obligations (NWC, 2008). In calculating the allowed revenue, regulators review assumptions regarding the efficient levels of operating and capital expenditure that the entity would need to meet target levels of service reliability and quality, expected growth in demand and customer numbers, and cost of capital financing over the regulatory period.

As outlined in Figure 4, annual revenue requirement is calculated as the sum of a return on capital, regulatory depreciation on the asset base, and operating and maintenance expenditure. Having determined the annual revenue requirement over the regulatory period, the regulators then set price caps based on assumptions about the maximum weighted average price change, increases in 


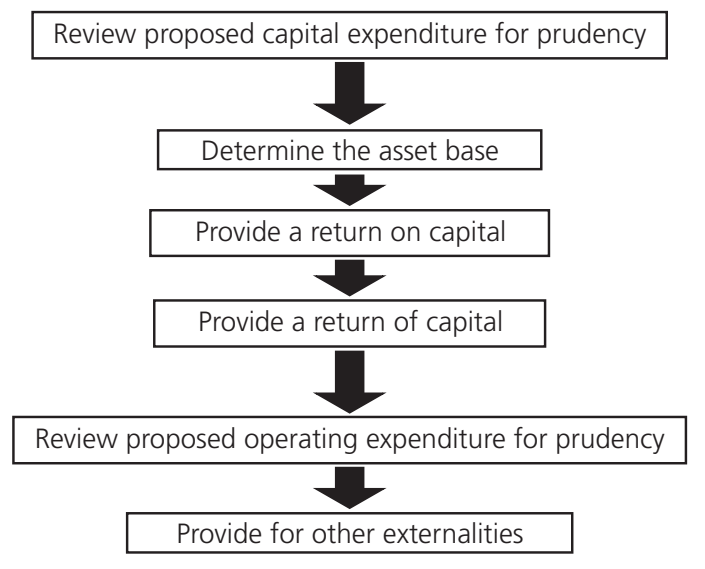

Figure 4. Typical process of determining Australian water utilities' revenue requirements (NWC, 2008)

inflation, and forecast customer numbers and demand over the regulatory period (NWC, 2008).

Given the above pricing approach and the prevailing drought in Australia during the first decade of this century, investment by utilities in water supply security projects is considered prudent capital expenditure. Provision for a return on and of this capital would be regarded as a justifiable component of a utility's revenue requirement. It is therefore reasonable to conclude that investment in water supply security projects would lead to an increase in the price of potable water.

Australia is one of the fastest growing markets for desalination. According to Stedman (2010), in 2008 Australia produced only $300000 \mathrm{~m}^{3}$ of desalinated water per day for potable and industrial consumption; this figure is expected to increase sevenfold by 2013. Starting with a $144000 \mathrm{~m}^{3} /$ day desalination plant at Perth in 2007, Australia now has a $125000 \mathrm{~m}^{3}$ /day plant at Gold Coast (near Brisbane) and a $250000 \mathrm{~m}^{3} /$ day plant in Sydney. Plants at Adelaide $\left(300000 \mathrm{~m}^{3} /\right.$ day $)$ and Melbourne $\left(450000 \mathrm{~m}^{3} /\right.$ day $)$ are under construction (Stedman, 2010).

This mass uptake of desalination would mean that water utilities' electricity usage would see significant increase. The cost of building desalination plants, as well as increased operational costs in line with increasing electricity prices, will be reflected in water prices across Australia. For instance, Melbourne, with the $450000 \mathrm{~m}^{3} /$ day desalination plant costing some $\mathrm{A} \$ 3.5$ billion, will see average household water bills increase by over $57 \%$ over the 2009-2013 price path (ESC, 2009). Figure 5 shows projected increases in household water bills over the current price determination period as a result of investment in desalination.

\section{Recycled water pricing}

A key element of the economic viability of water recycling schemes is the price charged to users. However, to date there has been little or no guidance or consistency on the methodology

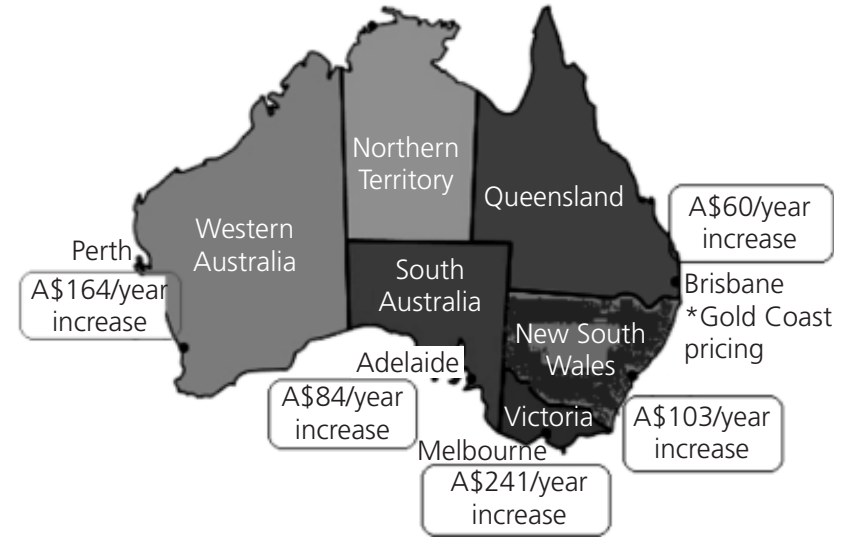

Figure 5. Predicted increase in household water bills due to desalination costs (The Australian, 2010)

used for pricing recycled water across Australia (WSAA, 2005). The recycled water pricing approach throughout the country has tended to be ad hoc, varying from project to project.

In a survey commissioned by WSAA (2005), information was sought on key drivers, uses of water and pricing methodology adopted for existing recycled water schemes in Australia. Information was collected for 142 water recycling schemes owned and operated by WSAA member utilities in 2005. The water from these schemes was being used in households, industry, sporting fields and agriculture. The survey revealed that a considerable proportion (44\%) of the surveyed schemes did not charge anything or charged just a minimal fee for recycled water. Similarly to waste recycling expansion to reduce solid waste going to landfill, a number of these schemes were driven by the need to find a secure means of disposing of effluent rather than achieving an economic return. However, many of the water authorities owning these zero-charging schemes indicated an intention or hope to charge for recycled water in the future (WSAA, 2005).

Figure 6 shows that only 3\% of the schemes surveyed in 2005 charged more than 50 cents $/ \mathrm{m}^{3}$ for the recycled water they supplied. A prominent finding of the WSAA survey was the significant positive relationship between the use of water in agriculture and non-zero pricing. This relationship echoes previous findings on solid waste recycling that 'users' willingness to pay for recycled products is directly proportional to the quality of those products relative to products made from virgin materials' (IC, 1990). Given this community's broad acceptance of recycled water as a suitable irrigation substitute for virgin water, there is greater willingness to pay for the use of recycled water for this purpose.

According to Davis and Steirer (2007), it is not currently uncommon for water utilities to establish pricing for recycled water that ignores the full cost of its provision. For instance, start-up capital costs are considered as a 'sunk cost' and excluded 


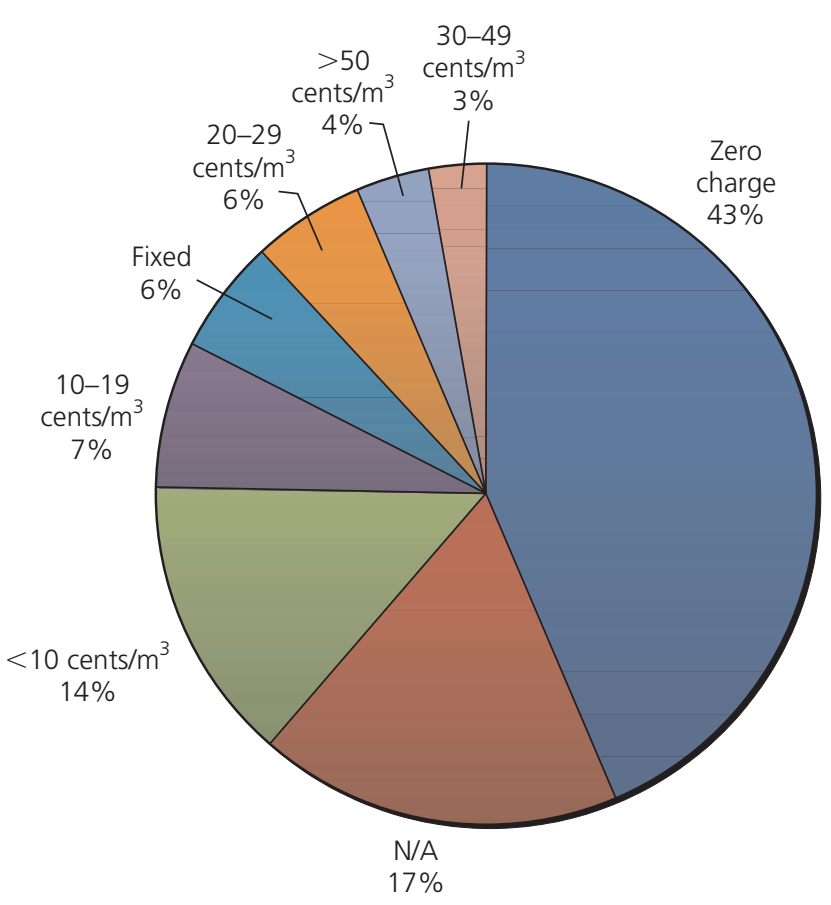

Figure 6. Recycled water pricing arrangements in Australia (WSAA, 2005)

from the pricing calculation. Similarly, costs of tertiary treatment may be ignored under the theory that these costs relate to wastewater treatment. In other examples, an overhead cost burden is allocated to water or wastewater rate calculations and excluded from the recycled water price (Davis and Steirer, 2007). These pricing approaches are being followed in an attempt to create a market for recycled water.

In order to be the alternative of choice, recycled water must be price competitive. That is, the recycled water price must be at or below the price of competing alternatives in order to ensure marketability (Davis and Steirer, 2007). If the recycled water rate were pegged to some percentage of the potable water rate for instance (as is done by San Diego Water Utilities in California, for example), customers could be assured a lower overall cost. Such an alternative pricing regime would pass the "marketability test' (Davis and Steirer, 2007). Similar to the findings of Davis and Steirer (2007), WSAA (2005) also states that the price of potable water will possibly place an upper limit on users' willingness to pay for recycled water as a substitute (see Figure 7). Wherever a low-cost supply alternative is available, the willingness to pay for recycled water will generally be low.

A clear implication of potable water price acting as a ceiling for recycled water price is that artificially low or subsidised water prices result in inhibiting the demand for recycled water. Figure 7 highlights that the foreshadowed increases in potable water prices across Australia could result in increased willingness to pay for recycled water. The willingness to pay for recycled water could

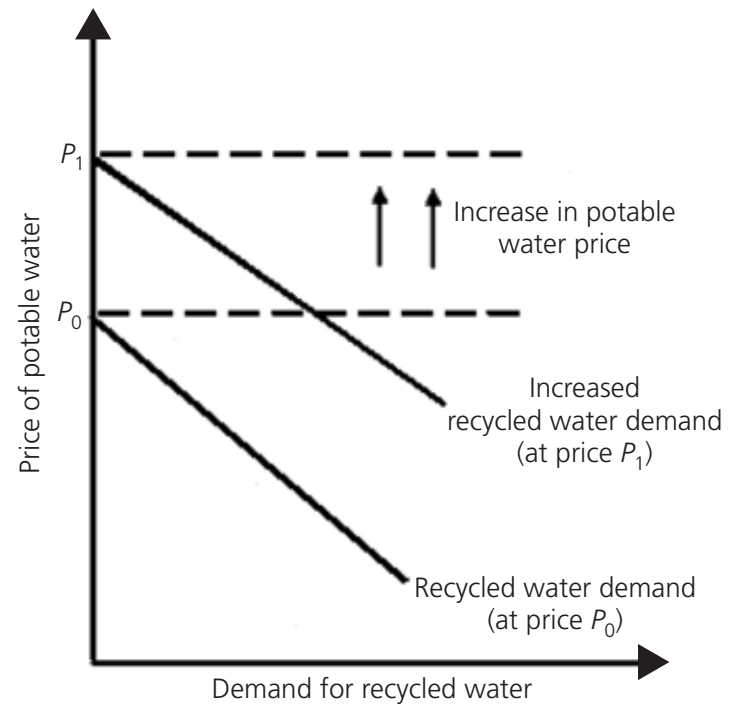

Figure 7. Recycled water price ceiling posed by potable water price (WSAA, 2005)

be further assisted by limited alternatives or, if there is uncertainty as to the ongoing security, price and/or quality of alternative water supplies in the future (WSAA, 2005).

\section{Case study}

The Beverley Park water reclamation plant is a flagship project under Kogarah City's total water cycle management strategy. The plant reclaims up to $750 \mathrm{~m}^{3}$ of sewage every day for treatment and reuse for irrigation at the Beverley Park golf club and other parks and sports fields within Kogarah City Council. The project has reduced potable water use in Kogarah by as much as $160000 \mathrm{~m}^{3} /$ year.

The cost of reclaimed water from Beverley Park plant was originally estimated to be $A \$ 1 \cdot 81 / \mathrm{m}^{3}$. This was based on a capital payback period of 15 years, with a positive return from the fifth year of operation (Chanan and Ghetti, 2006). The council was subsequently successful in receiving A $\$ 1.66$ million of the total project costs in state government grant funding. This funding injection reduced the council's own capital investment and allowed a revision of project economics, with the result that the project was able to offer recycled water at a price lower than the original estimate.

The principal author's personal involvement as project director of the Beverley Park water reuse project, which is Sydney's first ever sewer mining project, confirms the WSAA (2005) predictions on willingness to pay for recycled water. During the planning stages of the project in early 2004, Sydney was in severe drought and water storages dropped below $50 \%$. At the time, the New South Wales Minister for Utilities, Hon. Frank Sartor MP, made the remark that 'in 5 or 10 years time you won't be able to use drinking water from our dams to irrigate golf 
courses and outdoor playing fields' (ABC, 2004). This statement proved phenomenal in increasing the willingness to pay for the safer alternative of recycled water among golf club owners.

Sartor's statement foreshadowed a possible water management regime in which the use of recycled water for urban irrigation might become mandatory. As highlighted in Figure 8, 2004 was the only time during the life of the Beverley water reuse project that the local golf club expressed a willingness to pay a premium price for the use of recycled water. The statement and the prevailing stringent water restrictions due to drought at the time provided two external factors that potentially amplified perceived concerns regarding future water supply security for golf course irrigation. Another important extraneous factor that possibly contributed towards such high willingness to pay was the fact that the golf club's own investigations to source alternative water for irrigation at the time were largely unsuccessful.

As the project progressed from concept to reality, willingness to pay for recycled water shifted towards a more expected position of being below the potable water price. In 2006, the pilot plant produced recycled water at Beverley Park, the same year the NSW government announced plans to build the Sydney desalination plant. In 2008, at the time of plant commissioning, the price of potable water in Sydney was A $\$ 1 \cdot 61 / \mathrm{m}^{3}$. The golf club did not enter into an agreement to purchase water at this price; its willingness to pay for recycled water was much lower, perhaps influenced by easing drought conditions with Sydney's dam levels reaching well over $65 \%$. It is possible that the golf club's willingness to pay was also influenced by the fact that Kogarah City Council was successful in securing funding from state government, thereby reducing required capital investment to deliver the project.

The golf club entered into an agreement to purchase recycled water from Beverley Park at a price of $\mathrm{A} \$ 1 \cdot 26 / \mathrm{m}^{3}$. The price that

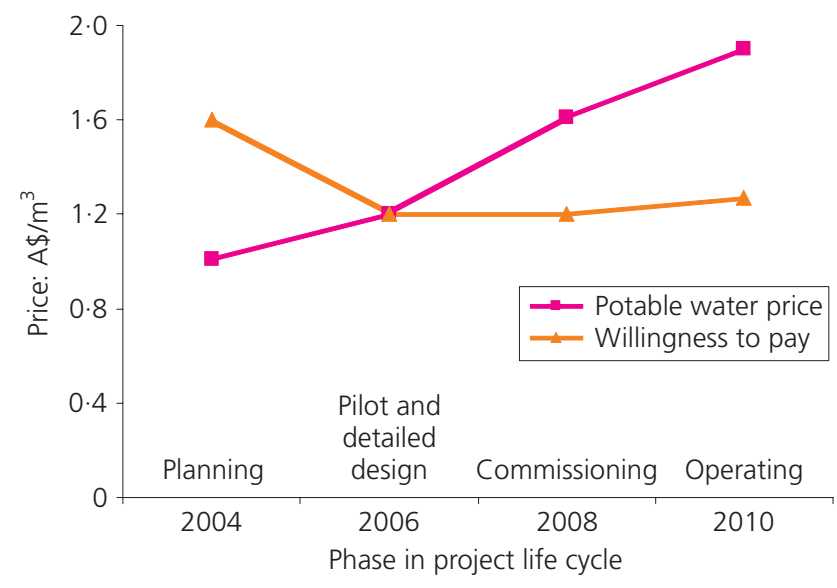

Figure 8. Comparison of willingness to pay and potable water price for Beverley Park water reuse project marked the golf club's actual willingness to pay was noticeably less than the $2009 / 10$ potable water price of $\mathrm{A} \$ 1 \cdot 90 / \mathrm{m}^{3}$. It is important to note that the club's decision was likely influenced by projected increases in potable water prices in Sydney resulting from large-scale investment in the desalination plant.

\section{Conclusions}

Any implementation of a $30 \%$ nationwide target for recycled water may result in an unnecessary increase in uneconomical large-scale water recycling projects. It is also likely that continuation of this policy approach may result in water recycling meeting the same fate as the solid waste recycling industry.

Possibly a better policy alternative to encourage economically viable recycling industry is the NSW government's Water Industry Competition Act 2006. The objectives of the Act and supporting regulations are to encourage competition in the water industry and foster innovative recycling projects and dynamic efficiency in the provision of water and wastewater services.

The willingness to pay for recycled water shows a direct positive link with the price of potable water (or other substitute). Therefore, a water pricing regime that reflects the true costs of water is critical in establishing an economically viable water reuse sector. Instead of promoting large-scale uneconomical reuse megaprojects that may result from a target-based policy, this approach is likely to encourage decentralised reuse initiatives with longterm economic viability. The NSW experience has resulted in Sydney having a large number of non-utility owned sewer mining projects currently underway. Incidentally, a number of these projects are owned by or have been implemented primarily to supply recycled water to golf clubs. It is important to note, however, that almost all of these projects have received state or federal government grants in the form of capital injection to cover initial construction costs.

With regard to a consistent approach in developing recycled water pricing, the gap has been acknowledged by the National Water Commission, which is currently working to improve pricing policies for recycled water. It is critical that these policies are consistent with the national water initiative commitments and are congruent with pricing policies for drinking water so as to stimulate efficient water use.

\section{REFERENCES}

ABC (2004) Watering Sydney: stateline interview with Hon Frank Sartor, New South Wales Minister for Utilities. See www.abc.net.au/stateline/nsw/content/2003/s1094677.htm for further details (accessed 29/04/2010).

Albanese A (2006) Action not Bureaucracy Needed for Water Crisis. See www.anthonyalbanese.com.au/file.php?file=/news/ APBUZYDLMTEXUIVPPOSTBZIO/index.html for further details (accessed 02/10/2010).

Chanan A and Ghetti I (2006) Beverley Park water reclamation project: pioneering water reclamation in Sydney. Proceedings 
of Institute of Public Works Engineering Australia, NSW Divisional Annual Conference 2006, Sydney. See www.ipweanswconference.com.au/downloads/presentations/ amitchanan.pdf for further details (accessed 17/03/2011).

Davis J and Steirer M (2007) A reclaimed water pricing approach that meets everyone's objectives. Proceedings of Water Environment Federation Conference 2007, California. Water Environment Federation, Virginia, USA. Session 21-30, pp. 2213-2224.

Dolnicar S and Schafer A (2009) Desalinated versus recycled water: public perceptions and profiles of the accepters. Journal of Environmental Management 90(2): 888-900.

EPHC (Environment Protection and Heritage Council of Australia and New Zealand) (2008) Australian Guidelines for Water Recycling. See www.ephc.gov.au/taxonomy/term/39 for further details (accessed 02/10/2010).

ESC (Essential Services Commission) (2009) Fact Sheet 1: Metropolitan Water Price Review Final Decision - Impact on Household Bills. ESC, Melbourne, Victoria, Australia.

Graham K (2006) Recycling Reality, 2 February 2006. See www.abc.net.au/science/features/recyclingreality/default.htm for further details (accessed 29/04/2010).

IC (Industry Commission) (1990) Interim Report on Paper Recycling. Australian Government Publishing Service, Canberra, Report no. 2.

IC (1991) Recycling, Volume I: Recycling in Australia. Australian Government Publishing Service, Canberra, Report no. 6.

IPART (2008) NSW Water Fact Sheet 4, Review of Prices for Sydney Water Corporation's Water, Sewerage and Stormwater Services. See www.ipart.nsw.gov.au/files/Fact\%20Sheet $\% 20$ Water\%204\%20-\%20 Review\%20of\%20SWC\%20prices $\% 20$ from $\% 2001 \% 20$ July\%202008\%20-\%20Jennie $\% 20$ Cooper\%20-\%2010\%20July\%202008\%20-\%20WEBSITE $\%$ 20DOCUMENT\%20Version.PDF for further details (accessed 04/05/2010).

MJA (Marsden Jacob Associates) (2008) National Snapshot of Current and Planned Water Recycling and Reuse Rates. Department of the Environment, Water, Heritage and the Arts, Canberra. See www.environment.gov.au/water/ publications/urban/pubs/national-recycling-snapshot.pdf for further details (accessed 12/05/2010).

NWC (National Water Commission) (2008) Approaches to Urban Water Pricing. Frontier Economics. NWC, Canberra, Waterlines occasional paper no. 7.

Oron FG (2003) Agriculture, water and the environment: future challenges. Water Science and Technology 3(4): 51-57.

PA (Planet Ark) (2005) Ten Years of Recycling - The Good, The Bad \& The Ugly. See http://recyclingnearyou.com.au/ documents/05nrw_gbugly_report-1.pdf for further details (accessed 12/02/2010).

PCA (Packaging Council of Australia) (2010) Issues Paper Recycling. See www.pca.org.au/site/cms/documents/issues/ issues08.html for further details (accessed 12/02/2010).

Radcliffe JC (2008) Australian Water Recycling Today - The Big Issues. See www.nwc.gov.au/resources/documents/Aus-Water-
Recycling-PRES-2705081.pdf for further details (accessed $15 / 06 / 2010)$.

Sheikh B (2008) Socioeconomic aspects of wastewater treatment and water reuse. In Efficient Management of Wastewater (Al Baz I, Otterpohl R and Wendland C (eds)). Springer, Berlin, pp. 249-257.

Stedman L (2010) Australia's explosive growth in desal. Water21 12(3): $16-21$.

TAG (The Australian Greens) (2009) Australian Greens Policy Water and Inland Aquatic Environments, Policy Category: A.

Environment. See http://greens.org.au/sites/greens.org.au/files/ policydownloads/

A4\%20WaterAndInlandAquaticEnvironments \%20Nov\%202009_0.pdf for further details (accessed 10/10/ 2010).

The Australian (2010) Water Charges are Set to Spiral in Desalination Squeeze. See www.theaustralian.com.au/news/ nation/water-charges-are-set-to-spiral-in-desalination-squeeze/ story-e6frg6nf-1225822705341 for further details (accessed $12 / 02 / 2010)$.

Tsagarakis KP (2005) Recycled water valuation as a corollary of the $2000 / 60 / \mathrm{EC}$ water framework directive. Agricultural Water Management 72(1): 1-14.

WSAA (Water Services Association of Australia) (2005) Pricing for Recycled Water. WSAA, Melbourne, occasional paper no. 12.

\footnotetext{
WHAT DO YOU THINK?

To discuss this paper, please email up to 500 words to the editor at journals@ice.org.uk. Your contribution will be forwarded to the author(s) for a reply and, if considered appropriate by the editorial panel, will be published as a discussion in a future issue of the journal.

Proceedings journals rely entirely on contributions sent in by civil engineering professionals, academics and students. Papers should be $2000-5000$ words long (briefing papers should be 1000-2000 words long), with adequate illustrations and references. You can submit your paper online via www.icevirtuallibrary.com/content/journals, where you will also find detailed author guidelines.
} 